\title{
STIGMA OG DEN RITUELLE ORDEN
}

\author{
Av Stipendiat Nicolay B. Johansen
}

Goffman's famous book, Stigma, is widely interpreted as a work in the interactionist tradition. However, the book is written in a conspicuously different language: the terminology of identity. Accepting that there are interactionist elements in the analysis Goffman presents, I argue that this book is better understood in the terminology of rituals introduced in Goffman's earlier writings, compiled in the book Interaction Ritual. Here the "self" is portrayed as a sacred unity, continuously paid homage in the encounters of everyday life. The rules governing the order of interaction secure that the fragile entity, the self, is not violated. In Stigma there are only remnants of the vocabulary from Interaction Ritual. The phenomenon of stigma is understood as occurring in the gap between "virtual and actual identity", and the "daily round" of the stigmatized is described as a matter of "information control". I argue that the vocabulary of sacred selves both illuminates the phenomenon Goffman addresses in Stigma, and further that it has a potential for clarifying unresolved puzzles in the book. When he terms meetings of stigmatized and normal people as a primary sociological scene, it might not be a reference to Presentation of Self in Everyday Life, but rather better understood as a reference to Durkheim's concept of deviance. Stigmatized people have, as the subtitle of Stigma suggests, "spoiled identities". They live with continuous experiences of what "normals", in Goffman's terms, would take as insults. They are experiencing "profanations". And these individual pains are an intrinsic part of the social demarcation of normalcy."

Goffmans bok Stigma fra 1963 er sannsynligvis en av de mest leste verkene i sosiologihistorien. Men er den alltid like godt forstått? Goffman leses av sosiologer og andre samfunnsvitere, deriblant kriminologer, så vel som at han hyppig brukes i de forskjellige retningene for sosialt arbeid som stadig fornyes. Goffman står på pensum for studenter innen kriminalomsorgen, sosionomstudiene og barnevern, bare for å nevne noen eksempler. Det er litt forskjellige utdrag som leses, men en bok som ofte brukes er Stigma.

Det problemet jeg ønsker å adressere i denne artikkelen, er at Goffmans fremstillinger sjelden stilles sammen med det som var hans sosiologiske prosjekt. Det er lett nok å gjengi noen av hovedpunktene i analysen, men hvordan henger disse

\footnotetext{
* Title in English: Stigma and the Ritual Order. Original in Norwegian.
} 
sammen med de store linjene i forfatterskapet hans? Det er ikke noe poeng å vise til forfattere som synder på dette punktet, siden det gjelder mange. Til og med Bourdieu, som samarbeidet med Goffman på slutten av hans liv, lar denne koblingen ligge. Bourdieu er svært rosende i sin omtale, men overfladisk (1999) og uten å berøre for eksempel spørsmålet om "samhandlingsorden" (2000). Mot Bourdieus synder fremstår nære og fjerne kollegers behandling av Goffman som mindre alvorlige. Jeg vil likevel påpeke noen problemer med denne måten å behandle forfatterskapet på, og da med fokus på Stigma.

Gjenfortellinger av bokens innhold har en tendens til å preges av det såkalte "dramaturgiske perspektivet" fra hans gjennombruddsbok, The Presentation of Self in Everyday Life fra 1959. Men Stigma er formulert mer eller mindre demonstrativt i en annen terminologi. Stigma er skrevet i et språk om identitet. Goffman skrev en rekke forskjellige bøker, og introduserte et nytt sett begreper og perspektiver i de fleste av dem. Det går imidlertid an å skjelne et hovedperspektiv i "samhandlingsorden". Flere hevder også, langs samme linjer, at han med sin ritualterminologi gjør seg til normsosiolog og durkheimianer (Album 1995, Becker 1999, Collins 1994, Manning 1992). Jeg vil i det følgende sette Stigma inn i det ritualsosiologiske perspektivet.

I den dramaturgiske terminologien finner vi et fremtredende aktørperspektiv. Presentation of Self... handler som tittelen antyder om hvilke strategier den enkelte tar $\mathrm{i}$ bruk for å styre andres inntrykk av en selv. Selv om man nok kan diskutere betydningen av fokuset på handling og rasjonalitet denne boken (se for eksempel Thorjussen 2004), er det lett å forstå at man tar Presentation of Self... til inntekt for en "handlingssosiologi". Samtidig med utgivelsen av Stigma florerte det også med andre mer eller mindre nykomponerte skoleretninger, som også fremhevet handlingselementet i det sosiale liv. Goffmans medstudent Becker publiserte sin Outsiders samme år (Becker 1973), en bok som skulle danne omdreiningspunkt for stemplingsteoretiske perspektiver. Goffmans samtid ble preget av disse perspektiver, og senere skulle fenomenologien og etnometodologien fylle ut dette bildet av sosiologiske skoleretninger med fokus på handlingsdimensjonen. Goffman ble dessuten (etter hvert) sterkt påvirket av disse retningene, men han passet hele tiden på å distansere seg fra et handlingsteoretisk ståsted. Temaet i boken Frame Analysis (1986[1974]), som av mange regnes som hans beste, er handlingsdimensjonen. Men samtidig sier han der eksplisitt at bokens tema er sekundært for sosiologien (side 13). Det er for meg åpenbart at det sosiale er det primære i en hver mellommenneskelig setting for Goffman. Handlingsdimensjonen, om den ble fortolket i et symbolsk interaksjonistisk univers eller et fenomenologisk univers, kunne aldri romme en uttømmende sosiologi.

Dette er mitt utgangspunkt, men det finnes flere synspunkter på saken. Det finnes de som hevder at Goffman "egentlig" skal forstås som symbolsk interaksjonist (for eksempel Rawls 2000). Dette gjelder spesielt Presentation of Self 
(Thorjussen 2004). Senere er Stigma tolket i samme lys (Sarbin og Kitsuse1994, Jacobsen og Kristiansen 2002, Hauge 2001)

Hovedpoenget i den videre teksten er ikke å slå fast at Goffman bare skal leses som durkheimianer. Forfatterskapet hans er uansett sammensatt av flere dimensjoner. Poenget er at man med en slik lesing går glipp av vesentlige momenter i den sosiologiske betydningen av stigmatisering som fenomen og Goffmans analyse av det.

I det følgende skal vi forholde oss til to hovedperspektiver på handling og stigma. Et perspektiv som fremhever den enkeltes skapende virksomhet som handlende subjekt. Her vektlegges gjerne den enkeltes definisjon av situasjonen og samspillet mellom de forskjellige partene. Det andre perspektivet setter det sosiale først, som oftest viser dette seg i givne regler som bestemmer situasjonen og retningen på handlingsforløpet.

\section{Stigma og identitet}

'Stigma' er fellesbetegnelsen på "situasjonen til et individ som er diskvalifisert fra fullstendig sosial aksept" sier Goffman (1995: 9). I denne formuleringen er det ingen åpning for grensetilfeller. Kan hende tenkte Goffman at fullstendig aksept er noe som kan forhandles, eller på andre måter konstrueres i den enkelte situasjon, men denne formuleringen peker i seg selv ikke mot noen slik tolkning. Det er senere et sentralt poeng at alle (praktisk talt) har erfaring med manglende aksept i enkelte situasjoner. Sannsynligvis er det mer rimelig å hevde at Goffman her viser til nokså robuste normer for hva som innvilger fullstendig aksept. Et stigma er noe som hefter ved et menneske, og som gjør dette mennesket litt mindre verdt:

\footnotetext{
"Begrepet stigma vil altså bli anvendt til å betegne en egenskap som er dypt diskrediterende, men det skal understrekes, at det det er behov for, ikke er et språk med vekt på egenskaper, men et språk om relasjoner" (Goffman 1995: 15, alle sitater er oversatt av meg (NBJ)).
}

Det er således et poeng at det er noen som definerer vedkommende som mindre verdifull, med henvisning til denne egenskapen. Men Goffman er ikke ute etter å problematisere disse definisjonene, snarere tar han dem for gitt, og omtaler senere i boken forsøk på å endre dem i pessimistiske vendinger. Nedenfor finner vi en annen formulering der definisjonsprosesser står sentralt.

"Samfunnet etablerer midler for å kategorisere personer og de egenskaper som føles vanlige og naturlige for medlemmer av de enkelte kategoriene" (Goffman 1995: 11).

Definisjonene er samfunnsmessig bestemt, han henviser til et utlevert sett med kategorier. Disse kategoriene fører til at vi kan forholde oss til andre, til dels 
ukjente mennesker uten vesentlige anstrengelser. De utleverte kategoriene legger til rette for at man kan plassere andre mennesker på grunnlag av iøynefallende egenskaper. Dette er en vesentlig ordensproduserende faktor. Når en fremmed nærmer seg kan vi raskt gjøre en vurdering av vedkommendes "sosiale identitet", altså vedkommende sosiale plassering.

Goffman deler sosial identitet opp i "faktisk identitet" og "virtuell identitet". Den faktiske identiteten hevder Goffman, handler om de egenskaper en person "beviselig" besitter. Virtuell identitet tar utgangspunkt i samfunnsmessig etablerte kategorier, hvor det vektlegges noen typer av egenskaper og stereotypier. Goffman definerer stigma som et brudd mellom den virtuelle og faktiske identiteten:

\footnotetext{
"Når en fremmed står foran oss, kan det vise seg at han har en egenskap som gjør ham annerledes enn andre i den kategorien av mennesker han kan være, og en egenskap som er mindre tiltrekkende - $\mathrm{i}$ ytterste fall en person som er tvers $\mathrm{i}$ gjennom ond, farlig eller svak. Han er således redusert i vår aktelse, fra å være et helt og alminnelig menneske, til en besmittet og mindreverdig person. En slik egenskap er et stigma, spesielt i det tilfelle når den diskrediterende effekt er sterk; noen ganger er det også kalt en feil, en tilkortkommenhet eller et handikap. Det utgjør en et spesielt misforhold mellom virtuell og faktisk identitet" (Goffman 1995: 12-13).
}

Misforholdet mellom faktisk og virtuell identitet åpner for at omverden betrakter mennesker med stigma på en annen og mer belastende måte enn det de selv mener det er grunnlag for. Stigma er for Goffman definert gjennom begrepet identitet.

\section{En sosiologisk primærscene}

Stigma er tematisk bredt anlagt, og tar for seg tre svært forskjellige former for mindreverdige egenskaper. Kroppslige deformiteter, karakterdefekter og egenskaper knyttet til det å tilhøre en gruppe. I de svært konkrete diskusjonene omkring forskjellige aspekter ved det å bære et stigma henter han historier om mennesker med cerebral parese, blinde, krøplinger, tunghørte, kriminelle, psykiatriske pasienter, prostituerte, negre og jøder. Bekjennelsen til en pike uten nese åpner boken. De uten stigma kaller han "normale", uten anførselstegn. ${ }^{1}$

Vi skal likevel ikke forstå fenomenet stigma i absolutte termer. Det som oppfattes som en moralsk defekt i en sammenheng, er det ikke i en annen. Samtidig har noen egenskaper som gjør at alle møter med andre mennesker vil være preget av denne, mens andre har egenskaper som bare unntaksvis er blamerende (eksempelet her er å besitte høyere utdannelse). Boken handler først og fremst om møter mellom mennesker med dominerende stigma og normale. I og med at normale har erfaringer med å besitte stigma i større eller mindre grad, er alle også i stand til å delta i samspillet med de stigmatiserte, og i dette samspillet finner Goffmån det han kaller en sosiologisk "primærscene" ("a primal scene of sociology"). ${ }^{2}$ 
På denne scenen finner vi blant annet et spill om informasjon, som Goffman kaller det, informasjon om klanderverdige egenskaper. Det er ikke alltid de tilstedeværende er klar over at en i deres midte bærer på et stigma. Goffman sondrer mellom de som er "diskreditert" og de som er "diskrediterbare", altså ennå ikke avslørte. Når omgivelsene er uvitende om den stigmatisertes tilstand åpner det seg flere typer av strategier. Man kan late som ingenting, og satse på at det ikke avsløres underveis i samhandlingen ("passing"). Noen ganger kan man også dekke til, aktivt skjule sin tilstand ("covering"). Begge disse strategiene må imidlertid veies opp mot den tilleggsbelastningen det vil være å bli avslørt. Da viser det seg ikke bare at man har en mindreverdig egenskap, man har også forsøkt å holde det skjult. Det er som vi skal se, en særlig klanderverdig måte å forholde seg til sin tilstand på.

Den stigmatiserte er ambivalent overfor fordømmelsen av seg selv, sier Goffman. "Han" (sic!) befinner seg i et spenningsfelt mellom det å assosiere seg med sine egne og de normale. På den ene siden er han en del av det samfunnet som fordømmer de egenskapene han selv besitter, på den andre siden identifiserer han seg med andre i samme situasjon som seg selv.

"(...) den stigmatiserte kan utvise ambivalens når han kommer i nærkontakt med sine egne
som oppfører seg i henhold til stereotypiene, mens de demonstrativt eller stakkarslig lever
ut de negative egenskapene de er tillagt. Dette synet kan fremkalle vemmelse, siden han
tross alt støtter de samfunnsmessige normer, men hans sosiale og psykologiske identifise-
ring med disse avvikerne knytter ham til det som fremkaller vemmelse, og transformerer
vemmelse til skam, og ytterligere transformerer skammen selv til noe å skamme seg over.
Kort sagt, han kan verken omfavne sine egne eller slippe dem" (Goffman 1995: 131-132).

I dette spenningsfeltet læres den stigmatiserte hvordan han kan presentere seg selv overfor forskjellige former for publikum. Han danner mønstre av passing og covering, og overfor hvem han skal avsløre seg. De råd den stigmatiserte her får, danner både utgangspunkt for en plattform og en slags politikk, men i tillegg gir de en oppskrift på å presentere et sømmelig "selv".

"A ikke leve opp til koden innebærer at man er en selvhøytidelig person på ville veier; å følge den betyr at man er både ekte og verdig, to åndelige kvaliteter som sammen kalles 'autentiske"' (Goffman 1995: 135).

Disse kodene innebærer også at den stigmatisertes ferd ute blant andre mennesker kretser rundt stigmaet. Man kan ikke på samme måte som normale være spontan $\mathrm{i}$ samhandlingen, man må ta seg i akt. For den enkelte kan det være svært forskjellige fordeler med å assosiere med henholdsvis "ens egne" og de normale. Med sine egne får han støtte for at de "egentlig" ikke er sånn som stereotypiene tilsier, at de egentlig er vanlige og har normale egenskaper (samtidig kan man være fri i forhold til de 
skammelige egenskapene). Dette er et politisk språk, sier Goffman, og kontrasterer det med et psykiatrisk språk, som de normale kan tilby. Om den stigmatiserte knytter sterke bånd til de normale får han høre at han er moden og at han har en god personlig tilpasning dersom han følger kodene for egen presentasjon. Om man feiler er man "forknytt, tvungen og i forsvarsposisjon med utilstrekkelige ressurser".

Den sosiologiske primærscene utspiller seg der normale og stigmatiserte befinner seg i såkalte "blandede selskap". Her vil den stigmatiserte være en i utgangspunktet normal person som tilfeldigvis er ekskludert fra enkelte arenaer i livet. De normale forlanger av den stigmatiserte at vedkommende ikke skammer seg eller benekter sin annerledeshet. Det forventes også at den stigmatiserte ikke fremviser bitterhet eller selvmedlidenhet. Goffman mener det er de stigmatiserte som har ansvaret for situasjonen i blandede møter, i den forstand at det er disse som må sørge for at samværet forløper uten pinlige episoder. Den stigmatiserte må først og fremst håndtere nedvurderende implikasjoner av de normales fremferd uten å lage nummer av det. Til dette kreves et sett med fortolkningsregler i møter med "glipper".

\footnotetext{
"Normale mener egentlig ikke noe vondt; og når de gjør, er det fordi de ikke vet bedre. De skal derfor taktfullt rettledes til å oppføre seg bedre. Slengbemerkninger og taktløsheter besvares ikke. Man skal enten overhøre dem eller vennlig opplyse om hvordan man ter seg, gjennom å stillferdig opplyse vedkommende, punkt for punkt, om at stigmatiserte til tross for sin fremtoning, faktisk er fullverdige mennesker" (Goffman 1995: 141).
}

Videre kreves det at den blamerte gjør det lettere for de normale å omgås stigmaet. Dette gjøres ved for eksempel å gjøre oppmerksom på at vedkommende har et slikt stigma, der dette ikke er åpenbart ved forste treff (for å hindre at den normale i uvitenhet kommer med uheldige bemerkninger). Eller ved at man gir forsamlingen en sjanse til å samle seg, før vedkommende entrer det sosiale samspillet. Man hjelper dem kort sagt med å være taktfulle mot en selv. Samtidig forventes det at man ikke strekker sin deltagelse i de normales samvær for langt. Den stigmatiserte skal således både oppføre seg som om vedkommende grunnleggende sett er normal, samtidig som man holder seg tilbake fra situasjoner hvor normale har problemer med å fremvise en tilsvarende aksept tilbake.

Kodene for den stigmatisertes tilpasning tilbyr vedkommende en "fantomaksept" sier Goffman. Dette er det beste den stigmatiserte kan håpe på. Akseptens fantomkarakter viser seg i at den forventes å ikke brukes i andre sammenhenger. Den gjensidige aksepten har karakter av en "liksomavtale", som begge vet ikke gjelder. På dette grunnlaget stiller han spørsmål om betydningen av stigmatisertes opptredener i slike blandede selskaper. En ting er at de beskytter de normale mot smerten og følelsen av urettferdighet som er forbundet med det å bære et stigma. Noe annet er at de normale slipper å bli konfrontert med deres begrensede tole- 
ranse og kan opprettholde en viss kontakt med dem uten å føle seg besmittet. Dette er faktisk grunnlaget for de kodene som regulerer den stigmatisertes tilpasning til blandet omgang i følge Goffman.

\section{Ritualer på grensen av det normale}

Det er altså et poeng at den stigmatiserte selv må ta ansvar for samhandlingen i blandede selskap. Vedkommende må anstrenge seg for å hindre at de normale kommer til å vise sin fordømmelse av egenskapene han bærer, og beskytte dem mot overdreven inkludering i deres fellesskap. Det er den stigmatisertes ansvar å opplyse de normale om hvordan de skal oppføre seg på skjønnsomt vis. Dersom den normale kommer til å glippe ut med en bemerkning som er nedlatende overfor de blamerte, skal denne overhøres, eller i hvert fall ikke besvares.

Det Goffman beskriver her, ligner det han i artikkelen On Face-work kaller håndtering av en "incident" (opptrinn). En "incident" defineres som "hendelser hvis effektive symbolske implikasjoner truer "face"' (Goffman 1982a: 12). Det er altså episoder som innebærer en trussel mot den måte de tilstedeværende har presentert seg selv. Begrepet "face" har en helt bestemt betydning i denne sammenhengen:

"Den positive sosiale verdi en person effektivt krever for seg selv gjennom den 'line' andre antar han har antatt i en bestemt kontakt" (Goffman 1982a: 5).

Begrepet "face" sies å være basert på en kinesisk begrepsbruk, men det fungerer også på både engelsk og norsk. Å miste ansikt kan på norsk bety at man blir "avslørt" som noe annet og mindre attraktivt enn slik man presenterte seg. Slikt er forbundet med forlegenhet. Face er noe som blir akseptert i situasjonen, det er noe man oppnår og opprettholder i løpende samvær med de andre.

Det er et konstituerende trekk at den enkelte knytter følelser til sitt face. Får man bekreftet et face man er vant med, vil man ikke legge merke til det, men dersom man får bekreftet et mindreverdig face enn ellers, blir man lei seg eller såret. Motsatt føler man seg vel. Det å komme med et forslag til face i en situasjon, kaller Goffman å fremføre en "line". ${ }^{3}$

Goffman foreslår videre en rik terminologi for bestemmelse av forskjellige samhandlingsmessige implikasjoner av dette perspektivet. For eksempel betyr det å være "in wrong face" å anta en line forskjellig fra det de andre i situasjonen er forberedt på. Det å være uforberedt på en situasjon kalles "out of face". På samme måte kan man "redde ansikt" både på engelsk og norsk. "To save face" betyr at man klarer å opprettholde en situasjon som om man ikke har "mistet ansikt" ("to be shamefaced"). Et uttrykk som ikke finnes på norsk er "to give face". Det betyr å arrangere for andre slik at de kan anta en bedre line enn de ellers ville vært i stand til, slik at vedkommende kan "gain face". 
Når man har fått utlevert et face vil man stå ansvarlig for dette i situasjonens videre forløp. Det betyr at man må våke over den informasjon som passerer i den videre utveksling. Man må passe på det Goffman kaller "expressive order", at det ikke kommer fram noe som ikke stemmer med det face man har. Når man følger med på strømmen av informasjon, må man sørge for å justere underveis. Om man gjør slike justeringer på vegne av seg selv, kalles det "pride" (stolthet). Om man justerer med hensyn til en større sosial enhet, snakker man om "honor" (ære). Når man passer på de elementer av utvekslingen som handler om hvordan den enkelte tar seg ut og hvordan vedkommende håndterer kroppen og sine følelser, er det tale om "dignity" (verdighet).

Og slik fortsetter Goffman å produsere en hel terminologi. Det første vi kan trekke ut av det som foreløpig er skissert, er at Stigma lett hadde latt seg formulere i og med terminologien fra On Face-work. Det hadde nok også vært en berikelse, for både temaet stigma og den foreliggende språkbruken. En person med et stigma havner kontinuerlig $\mathrm{i}$ situasjoner der vedkommende får utlevert et face med moralske defekter.

Der de normale i sin omgang seg i mellom har et utviklet sett av trafikkregler for å bevare hverandres ansikt, er reglene for blandet selskap uten tilsvarende gjenopprettende mekanismer. Dette viser seg særlig tydelig når vi tenker tilbake på det ansvar den stigmatiserte får for at samhandlingen med de normale skal fungere. Jeg innledet dette avsnittet med å hevde at det er en situasjon som minner om en incident. I begge tilfeller er det snakk om at en person havner i en situasjon der vedkommende blir konfrontert med de andres nedvurderinger. Det er imidlertid en vesenlig forskjell på den situasjonen som presenteres i Stigma og i Face-work. For normale gjelder det helt spesielle regler for hvordan man skal håndtere en slik hendelse.

I utgangspunktet gjelder det å unngå å stadfeste at det har funnet sted noe som truer en deltagers "face". Dette kan man gjøre ved å late som ingenting eller at man ikke la merke til det inntrufne. Alternativt kan man late som det ikke innebær noen trussel. Eller, man kan skjule følelsene sine og gi de andre anledning til å se bort. Så langt er forholdet mellom normale seg i mellom, og blandede selskaper med stigmatiserte nokså like. Men om hendelsen likevel ikke lar seg glatte over, har det i følge Goffman oppstått en "rituell ulikevekt", og en ny likevekt må etableres. Dette gjøres på følgende vis blant normale:

- Man finner ut om noen oppdaget at det forekom en trussel mot ens face.

- Den som kom med den truende informasjonen får tilbud om å rette på feilen, kompensere eller å straffe seg selv.

- Den som forvoldte ugjerningen kan akseptere tilbudet.

- Dersom forvolderen aksepterer, skal vedkommende vise tegn på takknemlighet. 
Det er dette Goffman kaller "face-work" (Goffman 1982a: 19-23). Modellen kan imidlertid fravikes, sies det. Da kan det blant annet tjene som fornærmelse og føre til voldelige represalier, - alternativt at den fornærmede forlater stedet.

Det er likheter mellom den stigmatisertes ansvar og håndteringen av slike hendelser. I begge tilfeller er det den som har mest å tape som tar ansvaret for situasjonen. Og Goffman klarer på sitt karakteristiske vis å forvirre våre forventninger om hvem som er offer og ansvarlig for situasjonen. Men det er en stor forskjell. Det finnes ingen gjenopprettende mekanisme for bæreren av stigma og vedkommendes face/identitet. Også for de normale er face-work et alvorlig spill. Menneskers følelse av egenverd står og faller på at man setter opp en line som er akseptabel for en selv og for omgivelsene. De har mye å tape, men de mellommenneskelige møter er regulert slik at deres self og face er godt beskyttet. Men det er ikke tilfelle for de stigmatiserte. For dem betyr dette at deres mindreverd blir bekreftet i en kontinuerlig strøm av interaksjon med omverdenen.

Stigma kritiseres av enkelte for å ta for lite parti for de stigmatiserte (Rasmussen 1975). Goffmans analyse kan til tider være distansert og lite følsom for de smerter som følger med det å bære på en egenskap som gjør en moralsk mindreverdig. Selv om dette også berøres flere steder i teksten, hadde det blitt enda tydeligere i språkbruken fra On face-work. For størrelsene face og self her er ikke bare trafikkregulerende enheter i en strøm av kommunikasjon. Det er "hellige størrelser".

"Self" er et hellig begrep sier Goffman. Og dette er grunnen til at selvet håndterer sine egne fornærmelser, slik vi så også var tilfellet i Stigma. I følge Goffman er det er alltid den som har minst insitamenter til å misbruke makten, som har delegert ansvaret for håndhevingen av bestemte situasjoner. The expressive order og utvekslingen face er gjenstand for kontinuerlig samarbeid. Man får og gir ansikt, og hjelper hverandre med å opprettholde dem. Som medlemmene i de australske stammene Durkheim skrev om i The Elementary Forms of Religious Life, låner man sin individualitet fra fellesskapet:

"(...) mens hans sosiale ansikt kan være hans mest personlige besittelse og sentrum for hans trygghet og glede, har han det bare til låns fra samfunnet; det vil bli trukket tilbake hvis han ikke oppfører seg på en måte som gjør han fortjent til det” (Goffman 1982a: 10).

Opprettholdelse av face tar slik sett form av et ritual. Dette viser seg særlig ved oppstart og opphold i samvær. I slike situasjoner utvises en særlig glede overfor de andre. Slik glede får i avskjeder betydning som et slags løfte om hvordan man vil bli møtt neste gang. Det samme finner man i hilsninger, som Goffman kaller "small salutations" (Goffman 1982b). I alle kulturer, sier Goffman, mobiliseres enkeltindivider til å bli selvregulerende deltagere i sosiale møter. En måte å gjøre dette på, går gjennom ritualet: Man må være oppmerksomme, knytte følelser til sitt self, ha et 
self som presenteres med et face, ha stolthet, ære og verdighet, omtenksomhet, takt og en viss porsjon "poise" (balansert fremtreden). "Ens ansikt (...) er hellig, og den ekspressive orden som kreves for å vedlikeholde det er derfor et ritual" (Goffman 1982a: 19). Goffman bringer følgende formulering i siste avsnitt i On Face-work:

\footnotetext{
"Universell menneskenatur er ikke en spesielt menneskelig ting. Ved å oppnå slik status, blir personen et slags konstrukt, ikke satt sammen av indre psykiske tilbøyeligheter, men av moralske regler innprentet utenfra. Disse reglene bestemmer, når de blir fulgt, hvordan han vil vurdere seg selv og de andre deltagerne i møtene, fordelingen av følelser og de typer av praksiser han vil inngå i for å oppnå en bestemt og obligatorisk rituell likevekt" (Goffman 1982a: 45).
}

Spillet rundt face utgjør små ritualer som bekrefter de enkelte menneskenes selvbilde. Det er imidlertid også en annen dimensjon ved ritualene; de bekrefter at reglene gjelder. Kommunikasjon i seg selv opprettholder således en samfunnsmessig orden gjennom at partene aksepterer spillereglene. Goffman mener dette elementet er en bærende grunn til at samfunnet overhodet er mulig, og ikke løser seg opp i kaos og konflikter.

Samhandlingens betydning for orden er om mulig enda tydeligere i artikkelen The Nature of Deference and Demeanor (1982b). Utgangspunktet er igjen Durkheims påpeking av at hyllesten til religiøse størrelser er integrerende for samfunnet. Det samme gjelder i smått for anerkjennelsen (hyllesten) til "personligheten": "ritene som blir utført overfor representasjoner av det sosiale kollektiv blir av og til utført overfor individet selv" (1982b: 47). Goffmans kompakte analyse føres nok en gang via et sett med begrepsbestemmelser, de viktigste her er "seremoni" og "ritual".

"I alle samfunn har regler for atferd en tendens til å bli formet til koder som garanterer at alle oppfører seg passende og mottar sitt. I vårt samfunn er koden som styrer substansielle regler og substansielle uttrykk gitt i lov, moral og etikk, mens koden som styrer seremonielle regler og seremonielle uttrykk er gitt i det vi kaller etikette. Alle våre institusjoner har koder av begge typer..." (Goffman 1982b: 55).

Goffman nøyer seg ikke med en terminologi for analyse av et avgrenset sosialt felt, terminologien representerer en måte å forstå samfunnet i stort.

"Slik seremoniell aktivitet finner vi kanskje aller mest tydelig i de små salutter, komplimenter og unnskyldninger som punktuerer sosialt samvær, og kan derfor betegnes som 'statusritualer' eller interpersonlige ritualer"' (Goffman 1982b: 57).

Selv om han tar for seg dagliglivets små hendelser, har disse avgjørende betydning i den store sammenhengen. Disse små hendelser er ladet med avgjørende verdi både for samfunnet som helhet og for det enkelte samfunnsmedlem, noe som er særlig skjebnetungt for den stigmatiserte. 
Det Goffman kaller "demeanor"4 handler om hvordan man kler seg, hvordan man ter seg, og ikke minst hvordan dette virker sammen. Demeanor inneholder også mer rituelle måter å presentere seg selv. Goffman skriver om enkelte pasienter på sykehuset, der han gjorde sine observasjoner, som oppførte seg i strid med gjeldende normer ved for eksempel matbordet. Å kontrollere "kroppsfunksjoner" (luft forskjellige veier) blir for ham en markør for hvordan man ser på seg selv. Goffman kaller dette å "profanere seg selv", altså gjøre seg selv til noe mindre enn det man er (noe ikke-hellig).

Med "deference" sikter Goffman til det aspekt ved ens fremtreden gjennom hvilken anerkjennelse av mottageren er formidlet. Dette aspektet er begrepsfestet med uttrykk som "feiring", "hengivelse" og "verdsetting".

\section{Ritualer i stigma?}

Spørsmålet er hva disse begrepene kan fortelle om forholdet mellom de normale og de stigmatiserte. Goffman skjelner mellom to typer av deference: "Avoidance-" og "presentational rituals". Unngåelsesritualer handler først og fremst om å ikke tråkke over den enkeltes intimsfære, sier Goffman. Man skal altså holde seg tilbake, ikke komme for fysisk nær hverandre og ikke stirre.

Presentasjonsritualer er mer ekspressive. Dette er handlinger hvor det markeres hvordan man ser på de andre i samhandlingen, noe som også innebærer et slags løfte om hvordan disse vil bli behandlet i fremtiden. Goffman nevner fire former: salutations, komplimenter, invitasjoner og "minor services". "Salutter" henviser til det vi forstår med forskjellige hilsener. Disse hilsenene virker som små bejublinger av den andres self. Det samme kan sies om komplimenter. Invitasjoner hevder han, er en måte å inkludere andre i selskapet. Å utføre mindre tjenester fungerer også som hilsener og komplimenter.

Goffman foretar ingen analyse av stigmatiserte menneskers møter med normale i forhold til denne begrepsdannelsen. Stigma gir likevel enkelte antydninger om hvordan en slik analyse kunne fortonet seg.

1. Det er lett å tenke seg eksempler på stigmatiserte mennesker som føler at omgivelsene er unnvikende i sin blikkføring.

2. Den samme usikkerheten, og kanskje vanskeligheten, som ligger i spørsmål om hvorvidt man skal hilse, kan forventes å bremse det som mellom normale ville vært vanlige komplimenter.

3. Kan hende vil også det sosialt veldig synlige stigmaet overskygge en eventuelt komplimentverdig egenskap?

4. Et hovedpoeng i Goffmans analyse av blandede selskaper er at de stigmatiserte bare er "med" $\mathrm{i}$ begrenset grad. De vil således ikke være invitert $\mathrm{i}$ store deler av de normales samvær. 
5. Når det gjelder mindre tjenester kan vi ane at Goffman ville snudd tematikken på hodet. Å skulle være hjelpende overfor stigmatiserte mennesker kan lett bli en måte å understreke deres hjelpeløshet eller stereotypier om sekundære tilkortkommenheter. Det som i de vanliges verden er hyllester kan således fungere som krenkelser i blandede selskaper.

Men Goffman var en uforutsigbar forfatter, få er de som kan uttale seg om hvordan han ville analysert et fenomen. Fra Stigma husker vi imidlertid at han la en særlig vekt på den såkalte fantomanerkjennelsen som blir de stigmatiserte til del i blandede selskaper. Om det er vanskelig å slå fast noe entydig effekt blandet selskap vil ha på det Goffman kalte presentasjonsritualer, er det rimelig å anta at vi i det minste vil finne en tydelig dissonans.

I og med at deltagelsen i blandede selskap på det seremonielle plan er sentrert rundt stigma, betyr dette innen ritualmetaforen at den stigmatiserte sjelden, eller kanskje aldri, får seremonielt bekreftet face som noe annet enn bærer at et stigma. Den ekspressive orden som regulerer samvær mellom mennesker innebærer at de enkelte deltagerne samarbeider om å ivareta hverandres face, som vi så beskrevet i Face-work. Om vi setter sammen bidragene i de to artiklene til Goffman, får vi altså fram et bilde av en samhandlingsorden som ikke virker for bærere av stigma. Der normale nøysomt unngår å fremheve egenskaper som kan virke uheldig for den enkeltes fremtoning, står dette tvert i mot i sentrum for samvær med de stigmatiserte. Om ikke substansielt så $i$ det minste seremonielt. Den deference som Goffman beskriver, settes ut av spill. Den rituelle anerkjennelse av de stigmatiserte fungerer ikke. I stedet for å være en hyllest av den andres hellige self, blir det en påpeking av at mottageren er noe mindre.

På samme vis forholder det seg i selskap med ens egne, som i sitt politiske språk også gjør stigmaet til det mest vesentlige. Her kan det likevel synes som om det seremonielle og substansielle blir snudd på hodet $\mathrm{i}$ forhold til blandede selskaper. Utover det politiske språket, settes stigmaene i sentrum ved at det blir fristeder for å leve dem ut, altså at man ikke behøver å skjule dem like aktivt som ute blant normale. Substansielt blir således de mindreverdige egenskapene viktige, samtidig som de seremonielt tiltaler hverandre uten de rituelle nedverdigelser som normale serverer.

Begrepene passing og covering viser til de stigmatisertes håndtering av sine stigma. I egne selskaper derimot, kan de altså vise seg fram med mindre blygsel, sier Goffman i Stigma. Forskjellen mellom disse fremvisningene forteller også om stigmatiserte menneskers vanskeligheter med å fremvise et demeanor som kan utløse alminnelig hyllest av vedkommendes hellige self. Snarere har de en mer eller mindre synlig egenskap som fremhever noe moralsk problematisk. Stigma fungerer på den måten som ceremonial profanations. Profanering er et uttrykk som 
peker på self som hellig størrelse. Goffman skriver først og fremst om profanering av andre. Eksemplene henter han fra en sterkavdeling på sykehuset han gjorde feltarbeid. Der kan profanering foregå på en slik måte at fornærmelsen ikke kan overses: Spytting, slag, skriking. Å kaste ekskrementer på en annen person er, uansett hvor syk vedkommende måtte være, å bruke et seremonielt "idiom", like "exquisite" som et "dypt bukk". Det er det samme rituelle språket. Man kan også profanere seg selv, så vel fysisk som verbalt. $\AA$ smøre seg inn med ekskrementer blir igjen det ytterste eksempelet, men Goffman legger til at å snakke om seg selv i nedlatende vendinger fungerer på samme måte. Å bære et stigma fungerer seremonielt som å ha et skilt med nedvurderende beskrivelse av en selv, eller et brennemerke i pannen. Og slik blir vi minnet på stigmabegrepets religiøse opprinnelse.

Men Goffman skriver altså ikke om stigma i et språk preget av ritualer og hellige self. Det mest påfallende med denne unnlatelsen, ligger i det åpenbare potensialet for å få fram grunnleggende dimensjoner ved livet som stigmatisert, som ligger i denne terminologien. Et poeng som Goffman ikke fremhever i Stigma, er for eksempel hvordan stigmatiserte mennesker ofte klandrer seg selv og på forskjellige måter gir uttrykk for selvhat. Vi kan bare spekulere $\mathrm{i}$ hvilke grunner som ligger bak Goffmans valg, men det hadde vært enkelt å sette dette sammen med hans perspektiv på self som en guddom. I The Nature of Deference and Demeanor presenterer han følgende knallperle:

"Profanering må man forvente, for en hver religiøs seremoni skaper muligheten for en sort messe" (Goffman 1982b: 86).

\section{Patruljering av normalitetens yttergrenser}

Selv om den er skrevet i en terminologi der identitet er det sentrale begrepet, er det mulig å finne spor av disse ritualperspektivene flere steder i Stigma. Kan hende er det også slik at forståelsen av denne teksten blir bedre med Goffmans ritualmetafor som tolkningsramme? Jeg nevnte innledningsvis at begrepet stigma forutsetter en definisjon av hva som er mindreverdig. Dette åpner i og for seg for seg for en slags forståelse av at avvikene er konstruert, eller i det minste kontingente, men dette er ikke noe dominerende perspektiv i teksten. Snarere er disse definisjonene tatt for gitt. Normene som regulerer den stigmatisertes ferd med sine egne, de inneforståtte og de normale er på samme måte uavhengige av enkeltaktører, og ikke tilgjengelige for endringsarbeid (selv ikke av det militante slaget).

"Så totalt er den enkelte produsert av samfunnet at samfunnet kan stole på at de som er minst akseptert som normale medlemmer, minst belønnet gjennom de gleder lettvint sosial samvær med andre gir, til å bidra med erklæringer, avklaringer og hyllest til den enkeltes indre" (Goffman 1995: 141). 
I dette utdraget skal vi legge merke til to ting: for det første ligger formuleringene tett opptil det durkheimianske perspektivet. Senere formulerer Goffman seg enda klarere i opposisjon til handlingsteoretiske posisjoner:

"Den normale og den stigmatiserte er ikke personer men snarere perspektiver. Disse genereres i sosiale situasjoner med blandede kontakter gjennom de urealiserte normer som omslutter møtet" (Goffman 1995: 164).

Normene er gitt, trafikkreglene bestemt, det er ikke mennesker som handler i situasjoner men "perspektiver som møtes", også når Goffman skriver i identitetenes terminologi. For det andre fremgår det (i sitatet på forrige side) at både den stigmatiserte og den normale er bærere av de samme normer, og at den stigmatiserte paradoksalt nok blir den viktigste forvalter av disse normer, når det er vedkommende som har minst glede av dem. Dette er en betydningsmettet observasjon, spesielt med tanke på at Goffman også erklærte at møter mellom stigmatiserte og normale utgjør en sosiologisk primaerscene. Foruten at dette begrepet er formulert med en dramaturgisk metafor, fremhever han at det foregår en utveksling her, som har en særlig sosiologisk betydning. Det som markeres i møter mellom stigmatiserte og normale, er normalitetens yttergrenser. Som Goffman selv påpeker ved flere anledninger, er det som vises i disse møtene, at partene deler samme normer. Det er et fellesskap som opprettholdes i disse møtene, samtidig som dette fellesskapet ekskluderer den ene parten.

Når Goffman omtaler møter mellom stigmatiserte og normale som en sosiologisk primærscene, er det nærliggende å tolke dette dit hen at man her på samme måte som $\mathrm{i}$ incidents og ved seremonielle ritualer - ja enda mer! - finner avgjørende øyeblikk både for samfunnets samhold og for den enkelte. På denne scenen bekreftes de sosiale normene, på samme tid som den enkelte blir tilordnet en plass i ordenen.

Slik kan man i alle fall fremføre en lesing av Stigma i forhold til den ritualsosiologiske terminologien. For det første gir dette en annen og bredere klangbunn enn å lese den på bakgrunn av Presentation of Self. For det andre kan man spørre om det er tilfredsstillende å tolke Stigma uten å ta hensyn til Goffmans store sosiologiske prosjekt. I utgangspunktet er det ikke det, men i tilfellet Goffman er det kanskje mindre utillatelig, siden forfatterskapet hans både er skrevet i et tilsynelatende virvar av terminologier, og at hans sosiologi i den grad er sammensatt av både handlingsteoretiske og normsosiologiske dimensjoner.

\section{Litteratur:}

Album, Dag (1995): Hvordan går det med Goffman og Garfinkel? I Sosiologisk Tidsskrift, Årg. 3, nr 4.

Becker, Howard S. (1973): Outsiders. The Free Press. 
Becker, Howard S. (1999): The Chicago School, So-Called. Qualitative Sociology 22 (1), 1999, pp. 3-12. Se også http://home.earthlink.net/ hsbecker/chicago.html. Bourdieu, Pierre (1999): Meditasjoner. Pax, Oslo.

Bourdieu, Pierre (2000): Discoverer of the infinetely small. I Fine, Gary Alan and Gregory W. H. Smith ed: Erving Goffman. Sage, London. Page 3-5.

Collins, Randall (1994): Four Sociological Traditions. Oxford University Press.

Goffman, Erving (1982a): On Face-work. I Goffman, Erving: Interaction Ritual. Pantheon books New York.

Goffman, Erving (1982b): The Nature of Deference and Demeanor. I Goffman, Erving: Interaction Ritual. Pantheon books New York.

Goffman, Erving (1990): The Presentation of Self in Everyday Life. Penguin books. Goffman, Erving (1995): Stigma. Notes on the Managment of spoiled identity. Penguin books.

Goffman, Erving (1961): Encounters. The Bobbs Merril Company.

Goffman, Erving (1986): Frame Analysis. Northeastern University Press.

Hauge, Ragnar (2001): Kriminalitetens Arsaker. Oslo, Universitetsforlaget.

Jacobsen, Michael Hviid og Søren Kristiansen (2002): Erving Goffman. Hans Reitzel Forlag.

Manning, Philip (1992): Erving Goffman. Polity Press, Cambridge.

Rasmussen, Svend Aage (1975): Stigma. I Gregersen, Bo (red): Om Goffman. 11 artikler. Hans Reitzel, København.

Sarbin, Theodore R. og John I. Kitsuse (1994): A Prologue to Constructing the Social, I Sarbin, Theodore R. og John I. Kitsuse (eds): Constructing the Social. Sage Publications.

Thorjussen, Esben (2004): Vårt rollespill til daglig: normsosiologisk, interaksjonistisk sui generis eller rasjonelt-aktør teoretisk? Hovedoppgave i sosiologi - Universitetet i Oslo.

\section{Noter:}

Jeg vil i fortsettelsen følge Goffmans praksis på dette området. Så vel forskjellige benevnelser av avvik som i dag fremstår som problematiske, som tilsynelatende nedverdigende betegnelser på bærere av stigma, vil bli gjengitt uten anførselstegn. Goffmans praksis på dette feltet kan leses som utslag av at han skrev i en tid der disse begrepene florterte lettere i dagligtalen enn tilfellet er i dag. Men det er også mulig å tolke det som uttrykk for at han betraktet disse posisjonene som reelle sosiale størrelser.

Om enn jeg holder meg unna anførseltegn i omtale av betegnelser på avvik, vil jeg bruke kursivering de stedene jeg bruker Goffmans terminologi.

2 Goffman er også oppmerksom på forskjellige typer forsamlinger. Bæreren vil forholde seg annerledes til en forsamling av mennesker med samme egenskaper ("the own"). De som er inneforstått med forekomsten av de stigmatiserende egenskapene og de tilhørende tilpasninger, og som kanskje også deler stigmafellesskapets oppfatninger av hva som er deres egentlige egenskaper, kaller han "the wise". Men bokens hovedtema er møter mellom normale og stigmatiserte. 
3 "Line" viser til den enkeltes syn på seg selv slik dette kommer til uttrykk i den konkrete situasjonen: "Et mønster av verbale og ikke-verbale handlinger gjennom hvilke man uttrykker sin definisjon av situasjonen, og dermed dens deltagere, særlig en selv (Goffman 1982a: 5). All samhandling rommer presentasjoner av en selv, eller mer presist "et selv". Selv om dette ikke er tema for samhandlingen vil det alltid være en dimensjon ved den.

4 "Det elementet i den enkeltes seremonielle oppførsel som typisk formidles gjennom atferd, påkledning og opptreden, som tjener til å uttrykke at vedkommende er en person med visse ønskelige eller ikke-ønskede kvaliteter, overfor de personer som befinner seg i vedkommendes umiddelbare nærhet" (Goffman 1982b: 77).

5 "Den komponent ved aktiviteten som symboliserer og formidler aktelsen av mottageren til mottageren, eller aktelsen av noe som denne mottageren symboliserer eller representerer. Disse tegn på hengivelse representerer måter en aktør feirer og bekrefter sin relasjon til en mottager" (Goffman 1982b: 56-57).

Adresse:

Institutt for kriminologi og rettssosiologi

Universitetet i Oslo

Postboks 6706

St. Olavs plass

$\mathrm{N}$ - 0130 Norge 